\title{
TURNING WASTE INTO USABLE PRODUCTS: A CASE STUDY OF EXTRACTING CHITOSAN FROM BLUE CRAB
}

\author{
${ }^{1}$ Camille Webster, ${ }^{2}$ Oghenekome Onokpise, ${ }^{1}$ Michael Abazinge, \\ ${ }^{2}$ James Muchovej, ${ }^{1}$ Elijah Johnson and ${ }^{3}$ Clifford Louime \\ ${ }^{1}$ Florida A\&M University, School of the Environment, Tallahassee, FL \\ ${ }^{2}$ Florida A\&M University, College of Agriculture and Food Sciences, Tallahassee, FL \\ ${ }^{3}$ University of Puerto Rico, College of Natural Sciences, San Juan, PR
}

Received 2013-10-10; 2014-06-20; Accepted 2014-06-24

\begin{abstract}
The purpose of this project was to develop a practical and cost efficient alternative to the current disposal of seafood waste in the North Florida region. Fortuitously, due to an unusually high turnover rate, this reconceptualization study may have turned seafood waste into a hot commodity. At least that is one conclusion one can draw from these findings. Indeed, over the past decades, under the pressure of volume and environmental concerns, Blue Crab (Callinectes sapidus Rathbun) waste, usually considered a nuisance in North Florida, has seen a historical shift in its disposal and utilization. From the 10 million lbs generated in the region last year, almost $30 \%$, compared to $10 \%$ the year before, has been processed into usable products. These products have found use in biotechnology, food, biomedical and environmental and agricultural industries. The latter was mainly processed in the form of chitosan, a chemical known to promote seed germination and control economically destructive fungal diseases. This reconceptualization of seafood waste could represent a new market or economic opportunity for limited-land owners in coastal areas all over the world.
\end{abstract}

Keywords: Three Rs, Reduce Reuse Recycle, Waste to Products, Seafood Waste, Chitin, Chitosan

\section{INTRODUCTION}

For the past decades, environmental concerns and population pressure have been forcing us to look for ways to turn waste into energy and other usable products (FAO, 1998). The concept of "Reduce, Reuse and Recycle" has become a way of life for municipalities the world over. Here in North Florida, the seafood industry has seen an unprecedented shift in the way it disposes and utilizes the waste generated from its processes, especially in the Blue Crab (Callinectes sapidus Rathbun) industry (Nnali and Oke, 2013). With a global landing of nearly $8 \times 10^{6}$ MT, Blue Crab has been considered as a major polluter, as $80-90 \%$ of its biomass is waste (Gandy, 2010). This waste, which is usually tucked in landfills across the region, has been deemed as a nuisance by environmental regulators. Not only its sheer volume, but also the odor emitting from it, have been ground to label the Blue Crab waste as a pollution stream. Therefore, finding alternatives to its disposal and utilization became inevitable.

As materials decomposition depends heavily on their chemical structure, most products derived from Blue Crab waste were chitin based (Leffler, 1997). Chitin is the second most abundant polysaccharide in nature (Hirano, 1996) and is found in the exoskeletons of insects, shells of crustaceans and in the cell wall of some fungi and algae (Jang et al., 2004). Chitin primarily serves as a structural and protective layer in animals and fungi (Khor, 2014). Chitin has $\beta(1-4)$ linked $\mathrm{N}$-acetylglucosamine repeated units and is crystalline in nature (Phillips and Williams, 2009). Chitosan is the fully or partially deacetylated form of chitin and structurally contains (1-4, 2 -acetamido-2-deoxy- $\beta$-D-glucan) and (1-4, 2-amino-2deoxy- $\beta$-D-glucan) residues (Khor, 2014). Chitosan has been found naturally in the cell walls of yeast and some Corresponding Author: Camille Webster, Florida A\&M University, School of the Environment, Tallahassee, FL 
fungi (Phillips and Williams, 2009; Zikakis, 1984). Chitosan has become commercially available from the deacetylation of shellfish chitin (Zikakis, 1984).

Chitosan is known for its biodegradability, antimicrobial, bioadhesive, biocompatibility, metal chelating, non-toxic and film-forming properties (Doxastakis and Kiosseoglou, 2000). It has been exploited as a renewable resource and has been demonstrated to be useful in the agriculture, biotechnology, food, biomedical and environmental industries (Kurita, 1998). Chitosan is prepared in many ways from the shells of crustaceans depending on its intended use and quality desired (Wang et al., 2004). The preparation of chitosan begins with the extraction of chitin and then treating chitin with hot concentrated $\mathrm{NaOH}$ (Riccardo et al., 1997). The extraction of chitin consists of three major processes: Demineralization, deproteinization and decolorization (Khor, 2014). The process of demineralization involves the removal of the mineral content of the shell with a low concentration of acid, while the deproteinization process involves the removal of the protein from the shell with a weak solution of a base (Khor, 2014). The decolorization involves the removal of the lipid pigment (carotenoid) and may be an optional process (No and Meyers, 1995). The process of deacetylation usually involves the use of concentrated $\mathrm{NaOH}$ under high temperatures $\left(90-110^{\circ} \mathrm{C}\right)$ (Riccardo et al., 1997).

The objective of this study was to extract chitin from the Blue Crab (Callinectes sapidus Rathbun) and produce chitosan. The composition and physicochemical properties of the chitosan produced were evaluated.

\section{MATERIALS AND METHODS}

\subsection{Crab Shell Preparation}

Approximately $800 \mathrm{~kg}$ of carapace refuse from the Blue Crab were obtained from a crab restaurant out and transported to the laboratory where it was washed with deionized water to remove adherent and soluble material. The shells were manually broken by hand into chunks of 10-25 mm. The shells were then stored at $4{ }^{\circ} \mathrm{C}$.

\subsection{Moisture Content Determination}

Approximately $200 \mathrm{~g}$ of shell chunks were weighed (CDI, 2002) and then dried in an Iso-Temp oven (Fisher Scientific) at $65^{\circ} \mathrm{C}$ for $72 \mathrm{~h}$. The dried shells were then weighed again and moisture content was determined (Black et al., 1965) Equation 1:

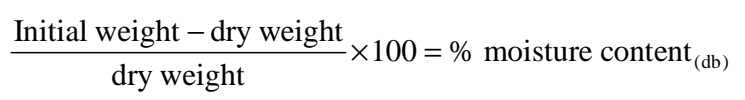

\subsection{Nitrogen, Calcium and Magnesium Content}

The dried crab shell sample was grounded to a particle size of $\pm 1 \mathrm{~mm}$. Approximately $10 \mathrm{~g}$ were placed in an airtight plastic container. The nitrogen, calcium and magnesium content of the dried crab shell sample were determined by the Feed and Environmental Water Laboratory, University of Georgia, Athens.

\subsection{Extraction of Chitin and Preparation of Chitosan}

\subsubsection{De Mineralization (DM)}

Crab shells $(100 \mathrm{~g})$ were placed in a 1-liter conical flask and $500 \mathrm{~mL}$ of $3.5 \% \mathrm{HCl}$ solution was added. The flask was then placed on an Innova 2300 platform shaker (New Brunswick Scientific) and shaken at 35 $\mathrm{rpm}$ at $25^{\circ} \mathrm{C}$. The $3.5 \% \mathrm{HCl}$ solution was changed daily by decanting and adding freshly prepared $3.5 \% \mathrm{HCl}$. On the $8^{\text {th }}$ day, $\mathrm{HCl}$ solution was decanted and the shells were washed with distilled water (241). The shells were then blotted dry with an absorbent paper towel and weighed (Fig. 1).

\subsection{Deproteinization (DP)}

The decalcified crab shell was deproteinated by adding $500 \mathrm{~mL}$ of $4 \% \mathrm{NaOH}(\mathrm{w} / \mathrm{v})$ solution to the shells in a 1-liter beaker. The mixture was then boiled in a water bath (Büchi B-481) at $65^{\circ} \mathrm{C}$ for $2.5 \mathrm{~h}$ after which the mixture was removed and let to stand and cool for $30 \mathrm{~min}$. The $\mathrm{NaOH}$ solution was then decanted and the shells were washed with distilled water (301) until the $\mathrm{NaOH}$ was removed. The shells were then blotted dry with an absorbent paper towel and weighed (Fig. 1).

\subsection{De Colorization (DC)}

The decalcified-deproteinated shells were then placed in a 1 liter conical flask and treated with $500 \mathrm{~mL}$ of $0.3 \%$ $\mathrm{NaOCl}$ at $25^{\circ} \mathrm{C}$ and shaken at $35 \mathrm{rpm}$ (Innova platform shaker) for $1 \mathrm{~h}$ to remove the carotenoid, astaxanthin. The chitin was then washed with $20,000 \mathrm{~mL}$ of distilled water until the $\mathrm{NaOCl}$ was removed. The chitin was then dried at $60^{\circ} \mathrm{C}$ for $24 \mathrm{~h}$ and weighed.

\subsection{De Acetylation}

The extracted chitin material was then treated with $50 \% \mathrm{NaOH}(\mathrm{w} / \mathrm{w})$ solution, boiled at $95^{\circ} \mathrm{C}$ for $4 \mathrm{~h}$ and then cooled. Evaporated water was replaced during the boiling process. The $\mathrm{NaOH}$ solution was then decanted. 


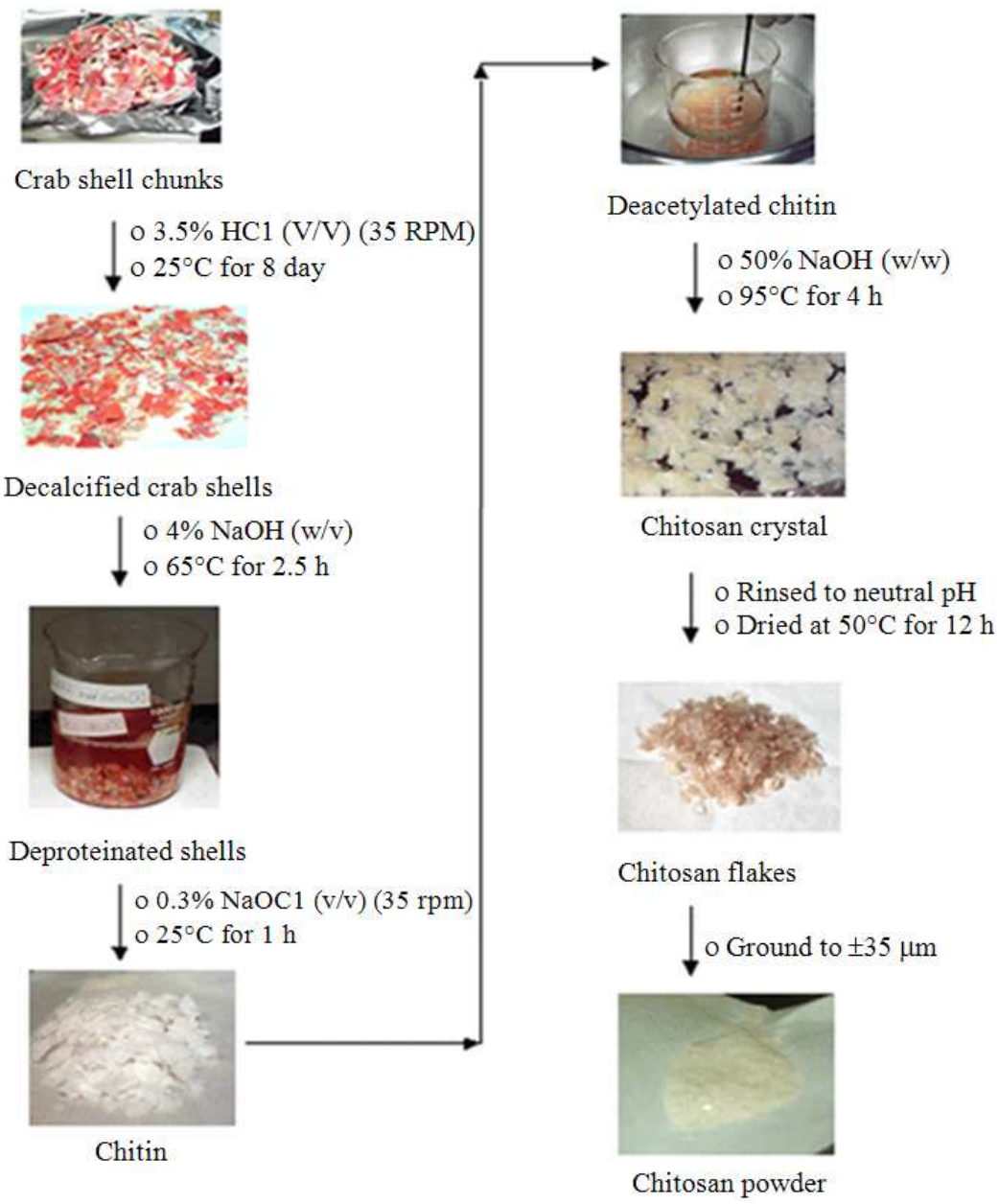

Fig. 1. Flow diagram of the production of chitosan from the Blue Crab (source: Personal)

The chitosan material was then washed until the $\mathrm{pH}$ (Accumet Research (AR) $15 \mathrm{pH}$ meter) was neutral, blotted dry with an absorbent paper towel, weighed and dried in an Iso-Temp oven (Fisher Scientific) at $50^{\circ} \mathrm{C}$ for $12 \mathrm{~h}$. After $12 \mathrm{~h}$, the dried chitosan was removed from the oven, placed in a dessicator for 5 min and weighed. Chitosan flakes were stored in airtight plastic tubes at room temperature for future use.

\subsection{Preparation of Chitosan Solution}

Chitosan flakes were ground using an Oster $700 \mathrm{~W}$ industrial blender to a fine powder of about $\pm 53 \mu \mathrm{m}$ in particle size. A4\% (w/v) solution of chitosan was prepared from the powdered chitosan by dissolving $4 \mathrm{~g}$ of chitosan in $100 \mathrm{~mL}$ of $1 \%$ acetic acid. The $\mathrm{pH}$ of the chitosan solution was recorded.

\subsection{Determining the Degree of Acetylation}

The degree of acetylation was done by elemental analysis according to Xu et al. (1996), by first obtaining the mass of Carbon (C) and Nitrogen $(\mathrm{N})$ of the extracted chitosan. The $\mathrm{C}$ and $\mathrm{N}$ content were determined by the Feed and Environmental Water Laboratory, University of Georgia, Athens. The Degree of Acetylation (DA) was calculated as follows Equation 2:

$$
\mathrm{DA}(\%)=[(\mathrm{C} / \mathrm{N}-5.14) / 1.72] \times 100
$$

where, $\mathrm{C} / \mathrm{N}$ is the ratio $(\mathrm{w} / \mathrm{w})$ of carbon to nitrogen. The mass of $\mathrm{C}$ and $\mathrm{N}$ were calculated from the organic fraction of the material. 


\subsection{Determination of the Bulk Density of Blue Crab Chitosan}

The bulk and particle densities of Blue Crab chitosan were carried out according to the American Society for Testing and Materials (ASTM, 2006) method D5004. Bulk density was determined by taking a chitosan sample of particle size, $0.5-1.0 \mathrm{~mm}$ and placing it in a $10 \mathrm{~mL}$ graduated cylinder to the $10 \mathrm{~mL}$ mark. The sample was then weighed. This procedure was repeated six times. Particle density was determined by placing the chitosan sample $(0.5-0 \mathrm{~mm}$ particle size) in a $10 \mathrm{~mL}$ graduated cylinder to the $10 \mathrm{~mL}$ mark and tapping the cylinder. The weight and volume were recorded. This procedure was also repeated 6 times.

\subsection{Precipitation Point of Bc-Chitosan and Elexa Solutions}

A1: 19 dilution of Bc-chitosan (4\%) and Elexa® were separately prepared in $100 \mathrm{~mL}$ volumetric flasks. To each volumetric flask, $5 \mathrm{~mL}$ of each solution was added and brought to a final volume of $100 \mathrm{~mL}$. The $\mathrm{pH}$ was determined and recorded. $\mathrm{NaOH}(1 \% \mathrm{w} / \mathrm{v})$ was then added drop wise to each solution (constantly stirring) until a precipitate was observed. The $\mathrm{pH}$ at which each solution formed a precipitate was determined and recorded.

\subsection{Data Collection}

A proximate analysis was done on the Blue Crab shell (carapace) and the extracted chitosan (Bc-chitosan). The physicochemical properties of Bc-chitosan and Elexa® 4 were characterized.

\section{RESULTS AND DISCUSSION}

The Blue Crab shell (carapace) had a chitosan yield of $6 \%$. The yield is low compared to $20-30 \%$ (Hirano, 1989) as reported in the literature. This low yield may be due to the source and amount of chitin. The carapace of the crab's exoskeleton had the least amount of chitin compared to the legs, which contains more chitin (Hirano, 1989).

Results from the proximate analysis of the carapace of the Blue Crab shell (Table 1) indicate a yield of $28 \%$ mineral matter $(\mathrm{Ca}-26 \%, \mathrm{Mg}-1.4 \%$ and other), $11 \%$ chitin, $45 \%$ residual protein and $1 \%$ lipid (carotenoid pigment).
Riccardo et al. (1997); Abram (2004), reported that crab shell generally contains $13-50 \%$ residual protein, $15-70 \%$ mineral matter, $10-40 \%$ chitin and $0-14 \%$ lipids. The proximate analysis is as described in the literature. The moisture content of chitosan was $10 \%$ (Table 1). The moisture content of the dried crab shell was $37 \%$ while the moisture content of chitosan stored was $10 \%$. Chitosan generally contains $<10 \%$ moisture (Breuel, 1992). Chitosan is readily absorbs moisture in nature. This indicates that moisture was absorbed during storage (Khan et al., 2002).

Chitosan extracted from the Blue Crab shell contained $<0.001 \%$ mineral matter $(\mathrm{Ca}$ and $\mathrm{Mg}$ ), $7.34 \%$ residual nitrogen (Table 1). The low mineral content suggests that the removal of $\mathrm{CaCO}_{3}$ and other minerals was effective. Roberts (1992), reported that crab shells that are properly demineralized will have a mineral content of $<1 \%$. The residual nitrogen in the Blue Crab chitosan was $7.34 \%$ (Table 1). The residual nitrogen (on a dry basis) found in crab and shrimp range from 7.06-7.97\% (No and Meyers, 1995). The residual nitrogen in Blue $\mathrm{Crab}$ is within the range reported in the literature.

The degree of acetylation of Blue Crab chitosan was 19\% (Table 2), indicating a high degree of deacetylation of $81 \%$. If the polymer contains $<50 \%$ of the acetyl group, the polymer is considered to be chitosan (Khor, 2014; No et al., 1995). The maximum level of degree of deacetylation that can be obtained in one single alkali treatment is $75-85 \%$ (Doxastakis and Kiosseoglou, 2000). Based on the degree of acetylation, the polymer in this study is chitosan. The untapped bulk density of Blue Crab chitosan was $0.24 \mathrm{~g} \mathrm{~mL}^{-1}$ while the particle density was $0.30 \mathrm{~g} \mathrm{~mL}^{-1}$ (Table 2).

The bulk density of commercial crab chitosan ranges from 0.18-0.33 $\mathrm{g} \mathrm{mL}^{-1}$ (No and Meyers, 1995). This variation in bulk density will depend on the particle size and the porosity of the chitin before it was treated.

The $\mathrm{pH}$ of Blue Crab chitosan and Elexa ${ }^{\circledR} 4$ was 5.18 and 3.10 respectively (Table 2 ). The $\mathrm{pH}$ of Elexa® 4 was reported as 3.3-3.5 on the Material Safety Data Sheet (MSDS). The pH of Elexa ${ }^{\circledR} 4$ was in the range reported on the MSDS. The higher $\mathrm{pH}$ of Blue Crab chitosan was probably attributed to the concentration of acetic acid (1\%) used. Most commercial chitosans in aqueous solutions are dissolved in $2 \%$ acetic acid. The $\mathrm{pH}$ of the chitosan, therefore, will be less acidic when a lower concentration of acid is used for dilution (No and Meyers, 1995). 
Table 1. Proximate components of the Blue Crab shell and chitosan

\begin{tabular}{|c|c|c|}
\hline Component & Blue Crab shell (carapace) (\%) & Chitosan (\%) \\
\hline $\mathrm{Ca}$ & 26 & $<0.001$ \\
\hline $\mathrm{Mg}$ & 01.4 & $<0.001$ \\
\hline $\mathrm{N}$ & ---- & $7.34^{\mathrm{R}}$ \\
\hline Protein & $45^{*}$ & ---- \\
\hline $\mathrm{C}$ & --- & 40.790 \\
\hline Ash & 28 & $<0.001$ \\
\hline Chitin & 11 & ---- \\
\hline Chitosan & 06 & ---- \\
\hline
\end{tabular}

R-Residual Nitrogen; * N×6.25

Table 2. Physicochemical properties of Blue Crab chitosan (powder and liquid) and Elexa ${ }^{\circledR} 4$

\begin{tabular}{llll}
\hline Properties & $\perp$ Bc-chitosan (Powder) & Bc-chitosan (aq) (4\%) & Elexa®4 (aq) \\
\hline Degree of acetylation $(\%)$ & $19 \%$ & --- & --- \\
Untapped bulk density $(\mathrm{g} / \mathrm{mL})$ & 0.24 & --- & --- \\
Tapped bulk density $(\mathrm{g} / \mathrm{smL})$ & 0.30 & -- & - \\
pH & 7.02 & 5.18 & 3.10 \\
Precipitation point $\mathrm{pH}$ & ---- & 6.65 & 6.55 \\
\hline
\end{tabular}

$\perp$ Bc-chitosan-Blue Crab Chitosan

The precipitation point of Blue Crab shell chitosan and Elexa ${ }^{\circledR} 4$ at the same dilution rate was 6.78 and 6.55 respectively (Table 2). According to Sandford (1989), chitosan is generally insoluble above $\mathrm{pH}$ 6.5. The higher precipitation point of Blue Crab chitosan may also be due to the concentration of the acetic acid $(1 \%)$ that was used for its dilution. As previously mentioned, the $\mathrm{pH}$ will be higher because of a weaker acid solution subsequently resulting in a proportionate higher precipitation point.

\section{CONCLUSION}

The proximate analysis and physicochemical properties of chitosan extracted from the Blue Crab are within the range of values reported in the literature; and consequently may validate the procedure used for the extraction.

It is recommended that further research be carried out on the purification of the large volumes of water used in the washing process at each stage in obtaining chitosan. This is very important, as a salt that resulted from the demineralization process $\left(\mathrm{CaCl}_{2}\right)$ is very high in $\mathrm{pH}$. Further processing of the wastewater containing calcium salt could be used as a mineral supplement in animal rations. This calcium salt may also be used to in soil remediation by liming acidic soils to adjust the soil $\mathrm{pH}$.

\section{ACKNOWLEDGMENT}

This study was partly supported in part through a grant from USDA-Foreign Agricultural Service (USDAFAS-OICD-RSE-Grant \#58-3148-2-088).

\section{REFERENCES}

Abram, A.P.D., 2004. Quitina y Quitosano: Obtencion, Caracterizacion y Aplicaciones. 1st Edn., Spanish, Pontifícia Universidad Católica del Perú, ISNN-10: 9972426599, pp: 312.

ASTM, 2006. ASTM book of standards. Am. Society Test. Mater., PA.

Black, C.A., D.D. Evans and R.C. Dinauer, 1965. Methods of Soil Analysis: Part 1: Physical and Mineralogical Properties, Including Statistics of Measurement and Sampling. 1st Edn., Madison, American Society of Agronomy, pp: 770.

Breuel, T.M., 1992. Fast recognition using adaptive subdivisions of transformation space. Proceedings of IEEE Computer Society Conference on Computer Vision and Pattern Recognition, Jun. 15-18, IEEE Xplore Press, Champaign, IL., pp: 445-451. DOI: 10.1109/CVPR.1992.223152

CDI, 2002. Mettler toledo PR2002 balance. Current Directions, Inc.

Doxastakis, G. and V. Kiosseoglou, 2000. Novel Macromolecules in Food Systems. 1st Edn., Illustrated, Amsterdam, Elsevier, ISBN-10: 0444829326, pp: 448.

FAO, 1998. Population Change-Natural ResourcesEnvironment Linkages in East and Central Africa. Population Programme Service (SDWP). FAO Women and Population Division. 
Gandy, R.L. 2010. Blue Crab advisory board. Status of the Fishery. Florida Fish and Wildlife Conservation Commission. Fish and Wildlife Research Institute. Crustacean Research Department.

Hirano, S., 1989. Production and Application of Chitin and Chitosan in Japan. In: Chitin and Chitosan: Sources, Chemistry, Biochemistry, Physical Properties and Applications, Skjak-Braek, G., T. Anthonsen and P. Sanford (Eds.)., Elsevier Science Publishers, Essex, pp: 37-43.

Hirano, S., 1996. Chitin Biotechnology applications. Biotechnol. Ann. Rev., 2: 237-258. DOI: 10.1016/S1387-2656(08)70012-7

Jang, M.K., B.G. Kong, Y. Jeong, C.H. Lee and J.W. Nah et al., 2004. Physicochemical characterization of $\alpha$-chitin, $\beta$-chitin and $\gamma$-chitin separated from natural resources. J. Polym. Sci., 42: 3423-3432. DOI: $10.1002 /$ pola.20176

Khan, T., K.K. Peh and H.S. Ch'ng, 2002. Reporting degree of deacetylation values of chitosan: The influence of analytical methods. J. Pharm. Sci., 5: 205-212. PMID: 12553887

Khor, E., 2014. Chitin: Fulfilling a Biomaterials Promise. 1st Edn., Burlington, Elsevier Science, ISBN-10: 0080999409, pp: 154.

Kurita, K., 1998. Chemistry and application of chitin and chitosan. Polymer Degr. Stabil., 59: 117-120. DOI: 10.1016/S0141-3910(97)00160-2

Leffler, M., 1997. Treasure from Trash. Is There Profit in Crab Waste. Maryland-Research, Education, Outreach Notes,

Nnali, K.E. and A.O. Oke, 2013. The utilization of fish and fish farm wastes in biogas production: A review. Adv. Agric. Sci. Eng. Res., 3: 1-1.
No, H.K. and S.P. Meyers, 1995. Preparation and characterization of chitin and chitosan-a review. J. Aquatic Food Prod. Tech., 4: 27-52. DOI: 10.1300/J030v04n02_03

Phillips, G.O. and P.A. Williams, 2009. Handbook of Hydrocolloids. 2nd Edn., Illustrated, Boca Raton, Elsevier, ISBN-10: 1845695879, pp: 948.

Riccardo, A., A. Muzzarelli, Martin and G. Peter, 1997. Chitin Handbook. 1st Edn., Grottammare Atec Edizioni, ISBN-10: 8886889011, pp: 528.

Roberts, G.A.F., 1992. Chitin Chemistry. 1st (Edn.)., Illustrated, Macmillan Press, London, ISBN-10: 0333524179, pp: 350.

Sandford, P.A., 1989. Chitosan: Commercial Uses and Potential Applications. In: Chitin and Chitosan: Sources, Chemistry, Biochemistry, Physical Properties and Applications, Skjak-Braek, G., T. Anthonsen and P. Sanford (Eds.)., Elsevier Science Publishers, Essex, pp: 51-64.

Wang, T., M. Turhan and S. Gunasekaran, 2004. Selected properties of $\mathrm{pH}$-sensitive, biodegradable chitosan-poly(vinyl alcohol) hydrogel. Polym. Int., 53: 911-918. DOI: 10.1002/pi.1461

Xu, J., S.P. McCarthy, A. Gross and D.L. Kaplan, 1996. Chitosan film acylation and effects on biodegradability. Macromol., 29, 3436-3440. DOI: 10.1021/ma951638b

Zikakis, J.P., 1984. Chitin, Chitosan and Related Enzymes. Academic Press, New York, ISBN-10: 0127809503, pp: 423. 